\title{
Assessment of urinary protein 1 and transferrin as early markers of cadmium nephrotoxicity
}

\author{
A M Bernard, H Roels, A Cardenas, R Lauwerys
}

\begin{abstract}
Transferrin and protein 1 , a sex linked $\alpha_{2}$ microprotein, were assayed in urine from 58 workers exposed to cadmium (Cd) in a nonferrous smelter and from 58 age matched referents. These two new markers of nephrotoxicity were compared with urinary $\beta_{2}$-microglobulin $\left(\beta_{2}-m\right)$, retinol binding protein (RBP), albumin, and $\beta$ - $\mathrm{N}$-acetylglucosaminidase (NAG). The response of protein 1 to $\mathrm{Cd}$ tubulotoxicity was similar to that of $\beta_{2}-m, R B P$, and NAG. In Cd workers, protein 1 had a correlation with urinary $C d$ $(r=0.56)$ similar to $\beta_{2}-m(r=0.48), R B P$ $(r=0.58)$, and NAG $(r=0.49)$. Values of these three low molecular weight proteins and of NAG were increased only in workers with urinary Cd higher than $10 \mu \mathrm{g} / \mathrm{g}$ creatinine. Urinary transferrin and albumin were similarly affected by exposure to $\mathrm{Cd}$. Their response, however, was clearly more sensitive than that of low molecular weight proteins. Prevalences of positive values of these two high molecular weight proteins were not only higher but also tended to rise at lower concentrations of $\mathrm{Cd}$ in urine or blood. This finding suggests that in some subjects subtle defects in glomerular barrier function may precede the onset of proximal tubular impairment after chronic exposure to $\mathrm{Cd}$. It remains to be assessed whether these subjects are more at risk of developing renal insufficiency.
\end{abstract}

The early nephrotoxic action of cadmium (Cd) in man can be detected on the basis of several urinary or bloodborne markers. ${ }^{1-3}$ Tests that are currently recommended for the health surveillance of populations exposed to $\mathrm{Cd}$ rely on the measurement of

Unit of Industrial Toxicology and Occupational Medicine, Catholic University of Louvain, Clos Chapelle-aux-Champs, 30.54. B-1200 Brussels, Belgium

A M Bernard, H Roels, A Cardenas, R Lauwerys urinary proteins which reflect the functional integrity of the tubule or the glomerulus according to their size. Low molecular weight proteins such as $\beta_{2}$ microglobulin $\left(\beta_{2}-\mathrm{m}\right),{ }^{4}$ retinol binding protein (RBP), ${ }^{56}$ or $\alpha_{1}$-microglobulin ${ }^{7}$ are currently used for screening for proximal tubular injury whereas the assay in urine of a high molecular weight protein such as albumin permits the assessment of glomerular filter selectivity, at least before tubular function is compromised. ${ }^{89}$ According to recent studies the urinary activity of $\beta$-N-acetylglucosaminidase (NAG) is also a sensitive indicator of excessive absorption of $\mathrm{Cd} .{ }^{1011}$

In this study we have assessed two new potential markers of incipient Cd nephropathy, urinary protein 1 and transferrin. Protein 1 is an $\alpha-$ microprotein (molecular weight 20000 ) which may be the equivalent in man of the androgen dependent rat $\alpha_{24}$-globulin. ${ }^{12}$ It is a sex linked protein that is excreted in greater amounts in the urine from men after puberty. The origin of urinary protein 1 is unknown but the data we have so far collected suggest that it might constitute a new marker of impaired tubular reabsorption. ${ }^{12}$

Urinary transferrin was determined because recent studies suggest that it may be a more sensitive index of glomerular barrier defect than the microalbuminuria test. ${ }^{1314}$ These two markers have been assayed in the urine from workers exposed to $\mathrm{Cd}$ in a non-ferrous smelter and compared with urinary $\beta_{2}-$ $\mathrm{m}, \mathrm{RBP}$, albumin, and NAG. The relation between these biochemical markers and indicators of exposure to $\mathrm{Cd}$ was also examined.

\section{Materials and methods}

STUDY POPULATIONS

The study was conducted on 58 male workers exposed to $\mathrm{Cd}$ in a non-ferrous smelter. The control group consisted of 58 age matched men recruited from a factory with no risk of exposure to Cd or other heavy metals. None of the exposed workers or referent subjects was occupationally exposed to lead or mercury as shown by the concentrations of these metals in blood $(<35 \mu \mathrm{g} / 100 \mathrm{ml})$ and urine ( $<5 \mu \mathrm{g} / \mathrm{g}$ creatinine). The characteristics of the two populations are summarised in table 1 . 
Table 1 Characteristics of control and cadmium exposed workers

\begin{tabular}{|c|c|c|c|}
\hline & $\begin{array}{l}\text { Control workers } \\
(n=58)\end{array}$ & $\begin{array}{l}\text { Cadmium workers } \\
(n=58)\end{array}$ & $p$ value \\
\hline $\begin{array}{l}\text { Age }(\mathrm{y})^{\star} \\
\text { Duration of exposure }(\mathrm{y})^{\star} \\
\text { Cd concentration in blood }(\mu \mathrm{g} / \mathrm{l}) \dagger \\
\text { Cd concentration in urine }(\mu \mathrm{g} / \mathrm{g} \text { creatinine }) \dagger\end{array}$ & $\begin{array}{l}43 \cdot 1(10 \cdot 4) \\
\overline{0} \cdot 89(0 \cdot 3-2 \cdot 9) \\
0.66(0 \cdot 14-2 \cdot 5)\end{array}$ & $\begin{array}{l}43.5(10 \cdot 5) \\
10 \cdot 4(6 \cdot 6) \\
6.54(1.6-51) \\
6.23(0.87-165)\end{array}$ & $\begin{array}{l}\text { NS } \\
\overline{<0.001} \\
<0.001\end{array}$ \\
\hline
\end{tabular}

*Arithmetic mean (SD).

+Geometric mean (range).

${ }_{+}^{+}$Student's $t$ test; NS p > 0.05.

COLLECTION OF BIOLOGICAL SAMPLES

A spot urine sample was collected from each subject and $4.5 \mathrm{ml}$ were immediately transferred to a tube containing $0.4 \mathrm{ml}$ of a $1 \mathrm{M}$ phosphate buffer $(\mathrm{pH} 7 \cdot 6)$ containing $0.2 \%$ sodium azide. A sample of venous blood was also taken and immediately separated into two portions, one for metals analysis (on an EDTA tube).and the other for serum separation. All samples were collected in metal free tubes or bottles and stored at $4^{\circ} \mathrm{C}$ until determination of protein.

\section{BIOLOGICAL ANALYSES}

Urinary creatinine was measured by Jaffe's method. ${ }^{15}$ The concentrations of protein 1, transferrin, albumin, RBP, and $\beta_{2}-\mathrm{m}$ were determined by an automated assay relying on latex particle agglutination. ${ }^{16}$ All the antibodies were obtained from Dakopatts, Denmark. The assay of protein 1 was calibrated with a batch of purified antigen provided by Dakopatts. Standards for the determination of albumin and transferrin were obtained from Sigma Chemical Co (St Louis, Missouri) whereas that for $\beta_{2}-\mathrm{m}$ and RBP consisted of proteins purified in our laboratory as described previously. ${ }^{17}$

The detection limits of these immunoassays in urine (10-fold dilution) were $5 \mu \mathrm{g} / 1$ for $\beta_{2}-\mathrm{m}$ and transferrin, $10 \mu \mathrm{g} / 1$ for protein 1 and RBP, and $50 \mu \mathrm{g} / 1$ for albumin. The activity of NAG in urine was measured by the automated fluorimetric assay described by Tucker $e t$ al. ${ }^{18}$

The determinations of $\mathrm{Cd}$ and lead in whole blood or urine were performed by electrothermal atomic absorption spectrometry (Perkin Elmer Zeeman
3030) using the stabilised temperature platform furnace coupled with a Zeeman effect background correction system. Total mercury in urine was analysed using an automated cold vapour atomic absorption technique. ${ }^{19}$

\section{STATISTICS}

Parametric tests (Student's $t$ test, Pearson's correlation) were applied on log transformed data for all biological parameters except serum $\beta_{2}-\mathrm{m}$. Prevalences of raised values were compared by $2 \times 2 \chi^{2}$ test with Yates' correction. These prevalences of abnormal values were calculated by using as a normal upper limit the mean (geometric except for serum $\beta_{2}$ m) plus two standard deviations of the results found in the control group. For serum $\beta_{2}-\mathrm{m}$ and urinary $\beta_{2}-\mathrm{m}, \mathrm{RBP}$, and albumin we also calculated the prevalence of abnormal results on the basis of the upper normal limits routinely used in our laboratory.

\section{Results}

Compared with the age matched referents, workers exposed to $\mathrm{Cd}$ had significantly higher concentrations of $\beta_{2}-\mathrm{m}$ in serum and of $\beta_{2}-\mathrm{m}$, transferrin, albumin, and higher NAG activity in urine. The mean values for urinary protein 1 and RBP did not differ between the control and Cd groups (table 2).

The prevalences of raised values of all biochemical parameters of nephrotoxicity were increased in the Cd group (table 3). The difference between the control and Cd groups, however, was significant only for the urinary output of albumin and transferrin.

Table 2 Indicators of nephrotoxicity in control and cadmium workers

\begin{tabular}{|c|c|c|c|}
\hline & Control workers & Cadmium workers & p value $\ddagger$ \\
\hline $\begin{array}{l}\text { Serum } \beta_{2}-\mathrm{m} \text { concentration }(\mathrm{mg} / \mathrm{l})^{\star} \\
\text { Urinary } \beta_{2}-\mathrm{m} \text { concentration }(\mu \mathrm{g} / \mathrm{g} \text { creatinine }) \dagger \\
\text { Urinary RBP concentration }(\mu \mathrm{g} / \mathrm{g} \text { creatinine }) \dagger \\
\text { Urinary protein } 1 \text { concentration }(\mu \mathrm{g} / \mathrm{g} \text { creatinine }) \dagger \\
\text { Urinary albumin concentration }(\mathrm{mg} / \mathrm{g} \text { creatinine }) \dagger \\
\text { Urinary transferrin concentration }(\mu \mathrm{g} / \mathrm{g} \text { cr }) \dagger \\
\text { Urinary NAG activity }(\mathrm{U} / \mathrm{g} \text { creatinine }) \dagger\end{array}$ & $\begin{array}{l}1.4(0.43) \\
53 \cdot 3(4 \cdot 7-255) \\
66 \cdot 4(14-378) \\
92 \cdot 7(14-845) \\
5 \cdot 6(2 \cdot 3-25 \cdot 5) \\
194(50-1710) \\
0.96(0 \cdot 18-2 \cdot 84)\end{array}$ & $\begin{array}{c}1 \cdot 81(0 \cdot 53) \\
107(11 \cdot 7-136000) \\
78(20-73000) \\
107(17 \cdot 3-16500) \\
8 \cdot 8(2 \cdot 6-331) \\
390(65-15700) \\
1 \cdot 3(0 \cdot 46-8 \cdot 76)\end{array}$ & $\begin{array}{l}<0.001 \\
<0.005 \\
\text { NS } \\
\text { NS } \\
<0.005 \\
<0.001 \\
<0.005\end{array}$ \\
\hline
\end{tabular}

*Arithmetic mean (SD).

+ Geometric mean (range).

$\ddagger$ Student's $t$ test; NS, p $>0.05$. 
Table 3 Prevalence of increased values of nephrotoxicity markers in control and cadmium groups

\begin{tabular}{|c|c|c|c|c|c|}
\hline & \multicolumn{2}{|c|}{ Control group } & \multicolumn{2}{|c|}{ Cd group } & \multirow[b]{2}{*}{ p value } \\
\hline & No & $\%$ & No & $\%$ & \\
\hline Serum $\beta_{2}-\mathrm{m}$ & $2^{\star}$ & $3 \cdot 4$ & 9 & $15 \cdot 5$ & NS \\
\hline Urinary $\beta_{2}-\mathrm{m}$ & $\begin{array}{l}2 \dagger \\
0^{\star}\end{array}$ & $\begin{array}{l}3 \cdot 4 \\
0\end{array}$ & $\begin{array}{l}6 \\
4\end{array}$ & $\begin{array}{r}10 \cdot 3 \\
6 \cdot 9\end{array}$ & $\begin{array}{l}\text { NS } \\
\text { NS }\end{array}$ \\
\hline & $0+$ & 0 & 5 & $8 \cdot 6$ & NS \\
\hline Urinary RBP & $2^{\star}$ & 3.4 & 5 & $8 \cdot 6$ & NS \\
\hline Urinary protein 1 & $1 \dagger$ & $\begin{array}{l}1 \cdot 7 \\
1.7\end{array}$ & $\begin{array}{l}4 \\
4\end{array}$ & $\begin{array}{l}6.9 \\
6.9\end{array}$ & NS \\
\hline Urinary albumin & $3 *$ & $5 \cdot 2$ & $\begin{array}{r}4 \\
13\end{array}$ & $22 \cdot 4$ & $<0.025$ \\
\hline $\begin{array}{l}\text { Urinary transferrin } \\
\text { Urinary NAG }\end{array}$ & $\begin{array}{l}2 \dagger \\
2 \dagger \\
1^{\star}\end{array}$ & $\begin{array}{l}3 \cdot 4 \\
3 \cdot 4 \\
1 \cdot 7\end{array}$ & $\begin{array}{r}11 \\
13 \\
6\end{array}$ & $\begin{array}{l}19 \cdot 0 \\
22 \cdot 4 \\
10 \cdot 3\end{array}$ & $\begin{array}{l}<0.025 \\
<0.01 \\
\text { NS }\end{array}$ \\
\hline
\end{tabular}

*The values higher than the mean +2 SD of the values (normal or $\log$ transformed) of the control group $\left(2.26 \mathrm{mg} / 1\right.$ for serum $\beta_{2}-\mathrm{m}$, $2.7 \mathrm{U} / \mathrm{g}$ creatinine for urinary NAG, and $0.324,0.24,0.607,14.8$, and $0.87 \mathrm{mg} / \mathrm{g}$ creatinine for urinary $\beta_{2}-\mathrm{m}, \mathrm{RBP}$, protein 1 , albumin and transferrin) are classified as positive.

†The values higher than the upper limits of normal used in the laboratory $\left(2.4 \mathrm{mg} / 1\right.$ for serum $\beta_{2}-\mathrm{m}, 20 \mathrm{mg} / \mathrm{g}$ creatinine for albumin, and $0.3 \mathrm{mg} / \mathrm{g}$ creatinine for both urinary $\beta_{2}-\mathrm{m}$ and RBP) are classified as positive.

$+\chi^{2}$ test; NS, $\mathrm{p}>0.05$.

In this population of workers the response of urinary proteins of high molecular weight to $\mathrm{Cd}$ exposure was thus clearly more sensitive than that of low molecular weight proteins. Calculations with the upper limits of normal values routinely used in our laboratory or the 95th percentiles of the values found in the present control group led to the same conclusion (table 3 ).

In the group of $\mathrm{Cd}$ workers the seven markers of nephrotoxicity were significantly correlated with the internal dose of $\mathrm{Cd}$, assessed on the basis of urinary $\mathrm{Cd}$ (figs 1 and 2) or the Cd concentration in blood (results not shown). Urinary protein 1 was as well correlated with urinary $\mathrm{Cd}$ as $\beta_{2}-\mathrm{m}, \mathrm{RBP}$, or NAG. The weakest correlation was that between the urinary concentration of transferrin and the concentration of $\mathrm{Cd}$. The relation between urinary albumin and $\mathrm{Cd}$ in exposed workers was noteworthy: it was as high as that between $\beta_{2}-\mathrm{m}$ and $\mathrm{Cd}$.

Dose response relations were established by combining referents and exposed workers and by dividing the total population into four classes according to the concentration of $\mathrm{Cd}$ in urine (fig 3) or in blood (fig 4).

For all the measured parameters, prevalences of abnormally raised values were significantly increased when the concentrations of $\mathrm{Cd}$ in urine or blood exceeded $10 \mu \mathrm{g} / \mathrm{g}$ creatinine in urine and $10 \mu \mathrm{g} / 1$ in blood (the values that are presently considered as critical for the development of Cd nephropathy). ${ }^{819-26}$ Prevalence of raised values for low molecular weight proteins showed no tendency to increase before these critical concentrations were reached. In some subjects, however, the serum concentration of $\beta_{2}-\mathrm{m}$,

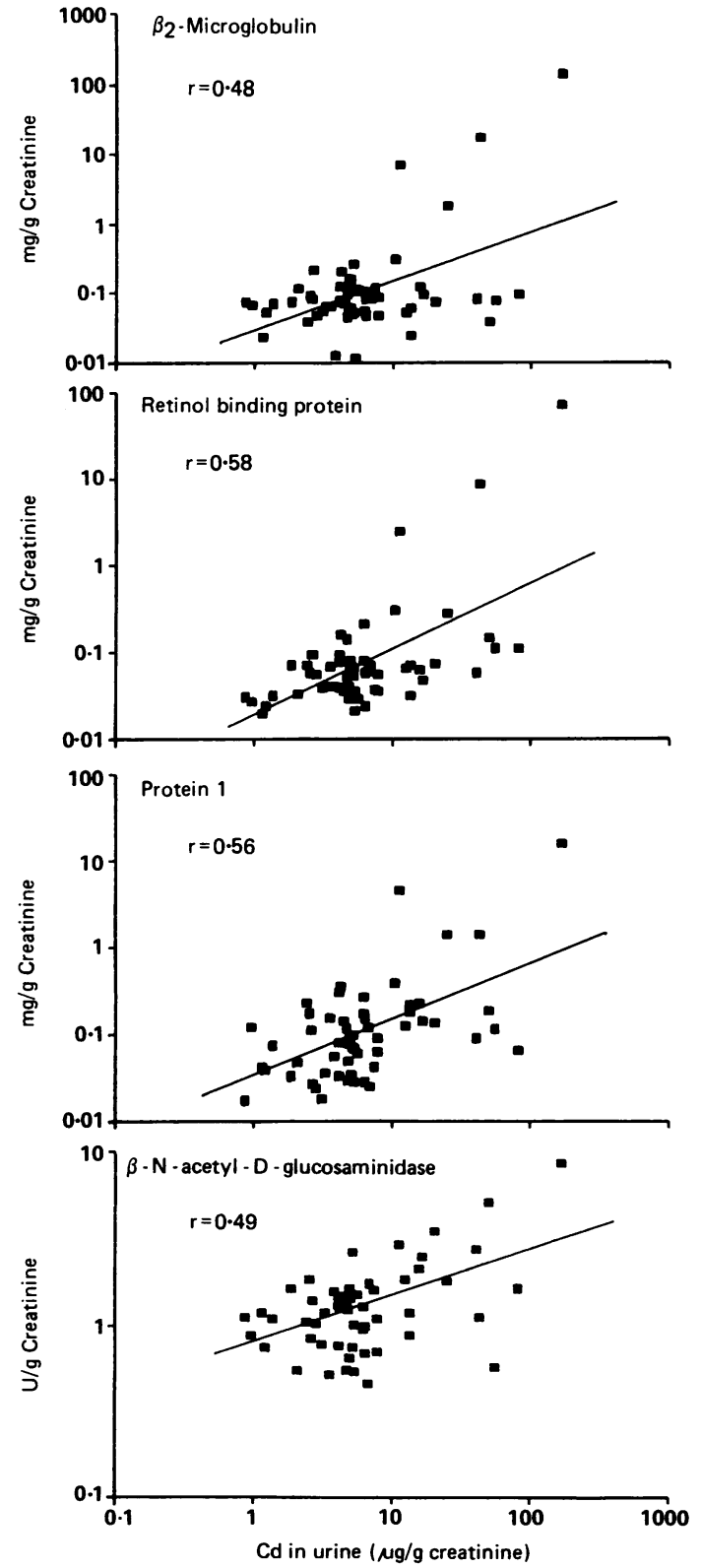

Figure 1 Correlations between urinary excretion of $\beta_{2}-$ microglobulin, retinol binding protein, protein $1, N A G$, and that of $C d$ in $58 C d$ smelter workers $(p<0.001)$.

and the urinary output of albumin and transferrin tended to become abnormal at a lower internal dose of $\mathrm{Cd}$. This phenomenon could not be ascribed to an age effect since the subgroups were well matched for age. 

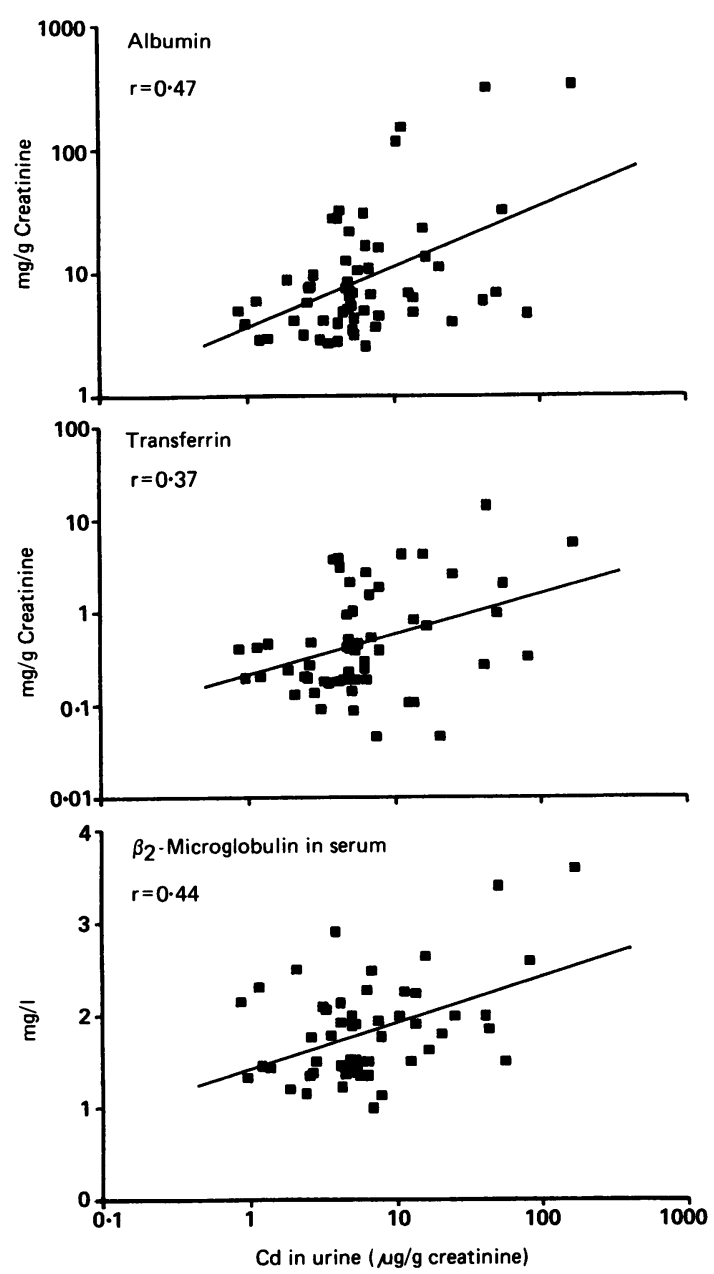

Figure 2 Correlations between albuminuria, transferrinuria, and serum concentration of $\beta_{2}-m$, and urinary excretion of $C d$ in $58 \mathrm{Cd}$ smelter workers $(p<0.005)$.

\section{Discussion}

The present study indicates that the behaviour of protein 1 in the urine of $C d$ workers is similar to that of $\beta_{2}-\mathrm{m}, \mathrm{RBP}$, and presumably other low molecular weight proteins. A feature of protein 1 which may be of interest for screening purposes is its extraordinary stability in urine, which is much superior to that of $\beta_{2}-\mathrm{m}$ and even RBP. Protein 1 is stable in a pool of normal urine incubated at $\mathrm{pH} 4$ and $37^{\circ} \mathrm{C}$ for $24 \mathrm{~h}$. Also, no degradation was found in urine samples that had been stored for six months at $4^{\circ} \mathrm{C}$ (A Bernard and colleagues, unpublished observation). The origin and biological function of this new protein are still unknown and little information is presently available about the physiological or pathological processes that may affect its concentration in biological fluids. ${ }^{12} \stackrel{\bar{\sigma}}{?}$ The sex dependency of urinary protein 1 suggests 0 that its synthesis is controlled by hormonal factors, in particular, androgens.

By contrast with the studies of Kawada $e t a l^{10}$ and $\mathbb{\Phi}_{\Omega}$ Chia et al, ${ }^{17}$, our data do not indicate that urinary NAG activity is a more sensitive indicator of renal tubular effects than $\beta_{2}$-m concentrations. Evidently? the urinary activity of NAG shows no greater ten- $\vec{\omega}$ dency to become abnormal at lower concentrations of $\mathrm{Cd}$ in blood and urine than $\beta_{2}$-m or other markers of proximal tubule injury. Nor does activity of this 3 enzyme correlate better with the internal dose of $\mathrm{Cd}+\overrightarrow{\mathrm{t}}$ than do other indicators of nephrotoxicity. A possible 0 explanation for these discrepancies might be in the matching between exposed and control workers, which was not perfectly achieved with respect to age $\Rightarrow$ in the study by Kawada $e t a l,{ }^{10}$ and in the study by Chia et $a l^{11}$ there were 65 exposed and only nine control workers.

It has been known for a long time that the urinary $\stackrel{5}{9}$ excretion of transferrin parallels that of albumin in $\vec{\theta}$ patients with enhanced glomerular leakiness. ${ }^{25}$ The recent introduction of sensitive immunoassays for comparing both proteins has shown, however, that they may respond differently to the early alterations of incipient glomerulopathies. In diabetic patients, urinary transferrin concentration proved to be a more sensitive index of early glomerular involvement than the determination of microalbuminuria. ${ }^{1314}$ In윽 the population of $\mathrm{Cd}$ workers examined here urinary transferrin concentration does not seem to detect the glomerular dysfunction induced by $\mathrm{Cd}$ at an earlier stage than albuminuria. This lack of an overt difference between both parameters is probably due to the fact that by contrast with diabetic nephropathy, $\frac{5}{3}$ which primarily affects the glomeruli, $\mathrm{Cd}_{-}$ nephropathy may affect both the glomeruli and the $\frac{O}{7}$ tubules. In most workers with $\mathrm{Cd}$ concentration in urine higher than $10 \mu \mathrm{g} / \mathrm{g}$ creatinine the increased응 loss of albumin and transferrin in urine is accom- $-\frac{D}{2}$ panied by an enhanced urinary excretion of low molecular weight proteins. In these workers the N comparison of urinary albumin and transferrin concentrations as indices of the glomerular filter selectivity is obviously confounded by the concurrent $\omega$ tubular impairment which can also cause a rise in? high molecular weight proteins in urine.

By contrast, the high molecular weight proteinuria found in workers with urinary $\mathrm{Cd}$ concentrations ${ }^{?}$ between two and $10 \mu \mathrm{g} / \mathrm{g}$ creatinine was not ${ }^{\circ}$ associated with signs of tubular damage. Seven $\frac{\text { + }}{\Phi}$ workers were positive on the basis of the albuminuria test and six on the basis of the transferrinuria assay but none had an abnormal urinary excretion of $\beta_{2}$-mo or RBP (the highest values were $212 \mu \mathrm{g} \beta_{2}-\mathrm{m}$ and $214 \mu \mathrm{g} \mathrm{RBP} / \mathrm{g}$ creatinine). The albuminuria of theseog 


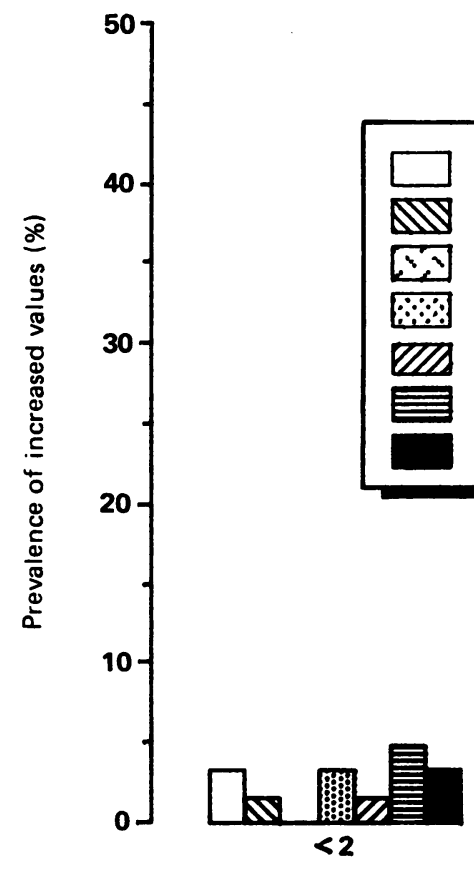

No of workers Age (SD)
61

$41 \cdot 3(11) y$ $\beta_{2-m, \text { serum }}$

NAG, urine

$\beta_{2}-m$, urine

$R B P$, urine

Protein 1, urine

Alb, urine

Tf, urine

Figure 3 Prevalences of raised values of markers of nephrotoxicity as a function of urinary Cd in Cd smelter workers and their referents. Prevalences were established on basis of upper limits of normal defined in control group and given in table 3 footnote a.

${ }^{\star}$ Statistically different from controls $\left(2 \times 2 \chi^{2}\right.$ test $)$.

workers was slight and below the threshold of detection by conventional dipstick tests. Nevertheless, if the criterion for diagnosing the presence of microalbuminuria in diabetic patients was applied ( $30 \mathrm{mg} /$ day or $20 \mathrm{mg} / \mathrm{g}$ creatinine) ${ }^{26}$ five must be considered as microalbuminuric. Although the numbers of $\mathrm{Cd}$ workers presenting with an enhanced albuminuria or transferrinuria without change in low molecular weight urinary protein excretion are practically the same, it is worth noting that on average, transferrinuria in these subjects was increased by a factor of 11 against a factor only half that for albuminuria.

The occurrence of a slight microalbuminuria or microtransferrinuria in Cd workers at exposure concentrations inferior to those considered currently as critical deserves special attention. Previous studies have reported that the rise of albuminuria in Cd exposed workers occurs concomitantly with or after the occurrence of proximal tubular dysfunction. ${ }^{392027} 28$ It should be emphasised, however, that in these studies albumin and other high molecular weight proteins were determined in urine by immunoprecipitation techniques (electroimmunoassay, nephelometry, or radial immunodiffusion) that are much less sensitive than most immunoassays presently used to detect microalbuminuria. The possibility that a slight increase in albumin excretion had been overlooked in these earlier studies cannot be excluded. Further studies are required to determine whether, as suggested by our data, subtle alterations of glomerular barrier selectivity may precede the onset of proximal tubular dysfunction in some workers chronically exposed to $\mathrm{Cd}$ and whether, as shown in diabetic patients, an isolated increased urinary excretion of high molecular weight protein after chronic exposure to $\mathrm{Cd}$ is predictive of an increased risk of renal insufficiency.

The finding in some workers (particularly among those with the highest internal dose of $\mathrm{Cd}$ ) of increased serum $\beta_{2}-m$ concentrations suggests a reduction in the glomerular filtration rate. As noted by other investigators, however, raised concentrations of $\beta_{2}-\mathrm{m}$ in serum are not always associated with 


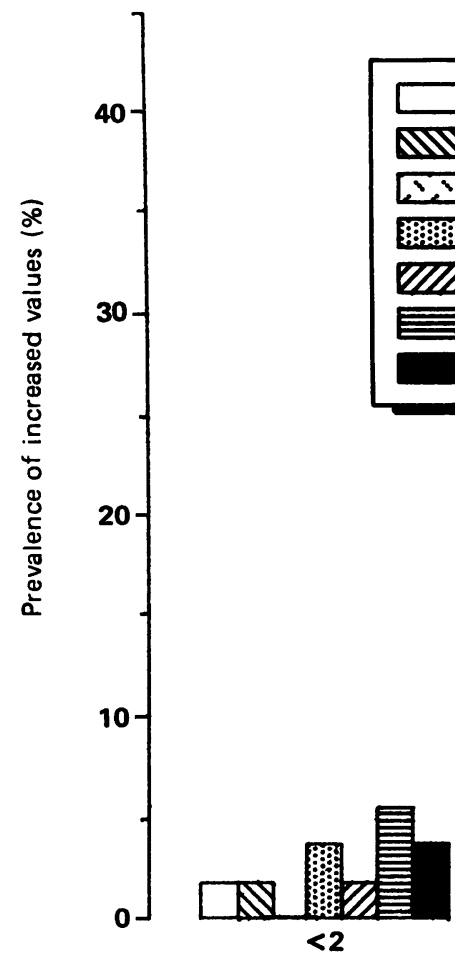

No of workers Age (SD)
55

$42 \cdot 6(11) y$
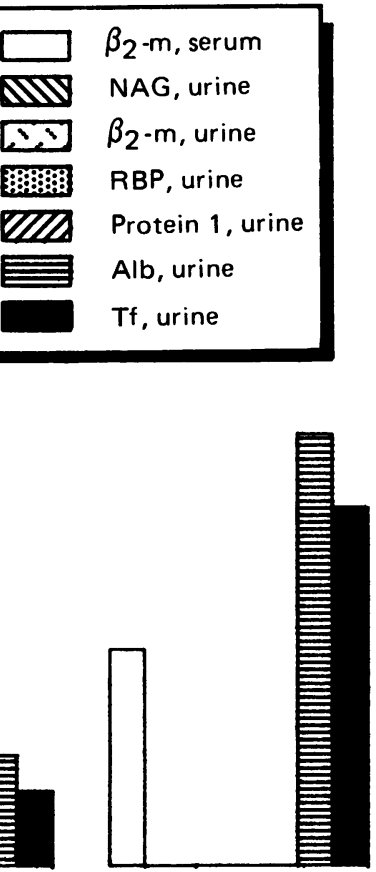

$2-5$

Cd in blood ( $\mu g / /)$

28

$44 \cdot 9(11) y$

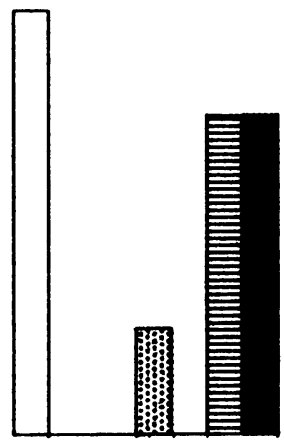

5-10

19
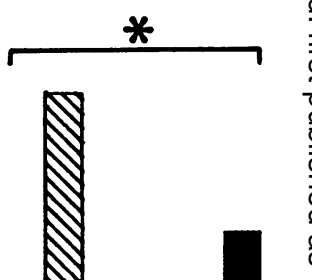

.

$\vec{\omega}$

Figure 4 Prevalences of raised values of markers of nephrotoxicity as a function of the Cd concentration in blood in Cd smelter workers and their referents. Prevalences were established on basis of upper limits of normal defined in control group and given in table 3 footnote a.

${ }^{\star}$ Statistically different from controls $\left(2 \times 2 \chi^{2}\right.$ test $)$.

a low or a high molecular weight microproteinuria. ${ }^{49}$ Of the seven workers with raised serum $\beta_{2}$-m concentrations $(>2.4 \mathrm{mg} / \mathrm{l})$, three showed no disturbances in the urinary excretion of specific proteins. Whether in these subjects the rise in serum $\beta_{2}-\mathrm{m}$ is caused by a reduction in the glomerular filtration rate or an enhanced synthesis of the protein ${ }^{30}$ also deserves further study.

We thank Dr $M$ Vinot for providing batches of polystyrene latex particles and the Dakopatts Company who kindly gave a calibrated preparation of protein 1. A Cardenas is research fellow of the Commission of the European Communities. A Bernard is Maitre de recherches du Fonds National Belge de la Recherche Scientifique.

1 Piscator M. The nephropathy of chronic cadmium poisoning. In: Foulkes EC, ed. Cadmium. Handbook of Experimental Pharmacology No 80. Berlin: Springer Verlag, 1986:179-90.

2 Bernard A, Lauwerys R. Early markers of cadmium nephrotoxicity: biological significance and predictive value. Toxicology and Environmental Chemistry (in press).

3 Lauwerys R, Bernard A. Early detection of the nephrotoxic effects of industrial chemicals: state of the art and future prospects. Am J Ind Med 1987;11:275-85.

4 Kjellström T, Piscator M. Quantitative analysis of $\beta_{2} \frac{D}{7}$ microglobulin in urine as an indicator of renal tubular damageindices by cadmium. Uppsala: Pharmacia Diagnostics $\mathbf{A B}$ 1977.

5 Bernard A, Lauwerys R. Retinol-binding protein in urine: $a$ more practical index than urinary $\beta_{2}$-microglobulin for the routine screening of renal tubular function. Clin Chem
$1981 ; 27: 1781-2$.

6 Topping M, Forster HW, Dolman C, Luczynska CM, Bernardo A. Measurement of urinary retinol-binding protein by enzyme linked immunosorbent assay, and its application to detection of tubular proteinuria. Clin Chem 1986;32:1863-6.

7 Itoh Y, Enomoto H, Kawai T. $\alpha_{1}$-microglobulin in cadmiumos poisoning. Nephron 1983;35:211-2.

8 Bernard A, Buchet JP, Roels H, Masson P, Lauwerys R. RenalO excretion of proteins and enzymes in workers exposed toO cadmium. Eur J Clin Invest 1979;9:11-22.

9 Gompertz D, Fletcher JG, Perkins J, et al. Renal dysfunction in $\varrho$ cadmium smelters: relation to in-vivo liver and kidney cad- $\vec{D}$ mium concentrations, Lancet 1983;i:1185-7.

10 Kawada T, Koyama H, Suzuki S. Cadmium, NAG activity, and $\beta_{2}$-microglobulin in the urine of cadmium pigment workers. Br J Ind Med 1989;46:52-5.

11 Chia KS, Ong CN, Ong HY, Endo G. Renal tubular function of 
workers exposed to low levels of cadmium. $\mathrm{Br} J$ Ind Med 1989;46:165-70.

12 Bernard A, Lauwerys R, Noël A, Vandeleene B, Lambert A Urine protein 1: a sex dependent marker of tubular or glomerular dysfunction. Clin Chem 1989;35:2141-2.

13 Bernard A, Ouled Amor AA, Goemaere-Vanneste J, et al. Microtransferrinuria is a more sensitive indicator of early glomerular damage in diabetes than microalbuminuria. Clin Chem 1988;34:1920-1.

14 Cheung CK, Cockran CS, Yeung VTF, Swaminothan $R$. Urinary excretion of transferrin by non-insulin dependent diabetics: a marker for early complications. Clin Chem 1989;35:1672-4.

15 Henry RJ, Cannon DC, Winkelman JW. Clinical chemistry: principles and technics. 2nd ed. New York: Harper and Row, 1974:552-4.

16 Bernard A, Lauwerys R. Continuous flow system for automation of latex immunoassay by particle counting. Clin Chem 1983;29:1007-11.

17 Bernard A, Lauwerys R, Starace V, Masson P. Isolation of a new low molecular weight $\beta$-globulin from urine of a worker with chronic cadmium poisoning. Biochem Biophys Res Comm 1980;93:535-43.

18 Tucker SM, Boyd PJR, Thompson AE, Price RG. Automatic assay of $\mathrm{N}$-acetyl- $\beta$-D-glucosaminidase in normal and pathological urine. Clin Chim Acta 1975;62:333-9.

19 Magos L, Clarksson T. Atomic absorption determination of total, inorganic and organic mercury in blood. Journal of the Association of Official Analytical Chemists 1972;55:966-71.

20 Buchet JP, Roels H, Bernard A, Lauwerys R. Assessment of renal function of workers exposed to inorganic lead, cadmium or mercury vapour. J Occup Med 1980;22:741-50.

21 Lauwerys R, Roels H, Regniers M, Buchet JP, Bernard A, Goret
A. Significance of cadmium concentration in blood and in urine in workers exposed to cadmium. Environ Res 1979;20:375-91.

22 Roels H, Bernard A, Buchet JP, et al. The critical concentration of cadmium in the renal cortex and in urine in man. Lancet 1979;i:221.

23 Roels $\mathrm{H}$, Lauwerys $\mathrm{R}$, Buchet JP, et al. In vivo measurement of liver and kidney cadmium in workers exposed to this metal. Environ Res 1981;26:217-40.

24 Bernard A, Lauwerys R. Cadmium, NAG activity, and $\beta_{2}$ microglobulin in the urine of cadmium pigment workers. $\mathrm{Br} J$ Ind Med 1989;46:679-80.

25 Pollack VE, Roy First M, Pexe AJ. Value of the sieving coefficient in the interpretation of renal protein clearance. Nephron 1974;13:82-92.

26 Mogensen CE. Microalbuminuria as a predictor of clinical diabetic nephropathy. Kidney Int 1987;31:673-89.

27 Verschoor M, Herber R, Van Hemmen J, Wibowo A, Zielhuis R. Renal function of workers with low-level cadmium exposure. Scand J Work Environ Health 1987;13:232-8.

28 Elinder CG, Edling C, Lindberg E, Kagedal B, Vesterberg $O$. Assessment of renal function in workers previously exposed to cadmium. Br J Ind Med 1985;42:754-60.

29 Elinder CG, Edling C, Lindberg E, Bertil K, Vesterberg $O$. $\beta_{2}$-microglobulinuria among workers previously exposed to cadmium: follow up and dose-response analyses. Am J Ind Med 1985;8:553-64.

30 Iwao $S$, Tsuchiya $K$, Sakurai $H$. Serum and urinary $\beta_{2}-$ microglobulin among cadmium-exposed workers. $J$ Occup Med 1980;22:399-402.

Accepted 15 February 1990

From 1 July 1985 articles submitted for publication will not be returned. Authors whose papers are rejected will be advised of the decision and the manuscripts will be kept under security for three months to deal with any inquiries and then destroyed. 